\title{
ANALISIS INJEKSI BAHAN BAKAR PADA INTAKE MANIFOLD MESIN BENSIN 4 TAK BERBAHAN BAKAR BENSIN DENGAN SIMULASI PEMODELAN
}

\author{
* Rasyid Hadi Sudono ${ }^{1}$ \\ ${ }^{1}$ Fakultas Teknik dan Informatika, Program Studi Teknik Mesin, Universitas Dian Nusantara, Jakarta, Indonesia
}

*Email Korespondensi:

rasyid.sudono@undira.ac.id

\section{ARTIKEL INFORMASI}

Diterima:

3 March 2021

Direvisi:

15 April 2021

Dipublikasi: 16 Mei 2021

\begin{abstract}
ABSTRAK
Untuk menghasilkan suatu kerja yang optimal dari mesin bensin, maka diharapkan pencampuran bahan bakar dengan udara terjadi dengan sempurna sesuai dengan kebutuhan mesin yang salah satu cara optimalisasinya adalah menggunakan metode injeksi bahan bakar ke intake manifold. Adapun salah satu metode analisa proses injeksi adalah menggunakan metode Computational Fluid Dynamics yang dapat dilakukan dengan program ANSYS FLUENT. Penelitian dilakukan dengan memodelkan salah satu model injektor dengan persamaan matematis serta menjadikan kecepatan pada inlet bervariasi. Hasil simulasi menunjukkan indikasi munculnya titik injeksi fluida yang cenderung bergeser lebih cepat seiring bertambahnya kecepatan inlet, kemudian dapat dilihat pula pada daerah dinding memiliki kecepatan yang rendah dikarenakan efek boundary layer, kecepatan yang rendah ini mengindikasikan pencampuran bahan bakar dan udara yang buruk.
\end{abstract}

Keyword: Computational Fluid Dynamics, ANSYS Software, Injektor, Kecepatan Aliran

\section{PENDAHULUAN}

Motor bakar torak adalah salah satu jenis mesin pembakaran yang mengubah energi kimia menjadi energi thermal, kemudian diubah kembali menjadi energi mekanik.

Motor bakar torak merupakan mesin dengan pembakaran dalam atau internal combustion engine (ICE). Motor bakar torak terbagi menjadi tiga jenis, yaitu motor bensin dan gas (otto) serta motor diesel. Perbedaan ketiga jenis motor tersebut yaitu motor otto menggunakan bahan bakar bensin dan gas sedangkan motor diesel menggunakan bahan bakar solar. Perbedaan yang utama terletak pada sistem penyalaan atau ignition. Pada motor bensin penyalaannya mengunakan busi sedangkan pada motor diesel penyalaannya memanfaatkan suhu kompresi yang tinggi untuk dapat membakar solar. Motor bensin merupakan salah satu jenis kerja motor bakar torak. Pada motor bensin, bahan bakar dinyalakan oleh loncatan api listrik antara dua elektroda besi. Pencampuran bahan bakar terjadi di luar silinder (ruang bakar). Pencampuran bahan bakar dengan udara pada motor bensin konvensional umumnya menggunakan karburator. 
Untuk menghasilkan suatu kerja yang optimal dari mesin bensin, maka diharapkan pencampuran bahan bakar dengan udara terjadi dengan sempurna sesuai dengan kebutuhan mesin. Oleh karena itu, dilakukan pengembangan teknologi tentang proses pencampuran ini dengan menggantikan karburator menjadi sistem injeksi bahan bakar. Tujuan pengembangan ini adalah untuk memperbaiki kinerja teknologi sebelumnya, diantaranya untuk merespon kebutuhan mesin akan campuran bahan bakar dengan udara. Selain itu, teknologi ini juga memenuhi tuntutan untuk penggunaan bahan bakar yang lebih ekonomis dan peningkatan kemampuan mesin.

Pada motor bensin, injeksi diharapkan terjadi pembakaran yang sempurna. Untuk itu sebelum masuk ke ruang bakar, pencampuran bahan bakar dengan udara haruslah baik. Sistem injeksi bahan bakar memiliki sensor yang dapat merespon kebutuhan mesin akan bahan bakar. Pada penyusunan skripsi ini, akan dibahas tentang bagaimana karakteristik semprotan bahan bakar didalam intake manifold dengan metoda simulasi pemodelan numerik pada motor bensin 4 tak.

\section{KAJIAN PUSTAKA}

\section{Motor Bakar}

Motor bakar adalah mesin atau pesawat yang menggunakan energi thermal untuk melakukan kerja mekanik, yaitu dengan cara merubah energi kimia dari bahan bakar menjadi energi panas, dan menggunakan energi tersebut untuk melakukan kerja mekanik. Energi thermal diperoleh dari pembakaran bahan bakar pada mesin itu sendiri. Jika ditinjau dari cara memperoleh energi thermal ini (proses pembakaran bahan bakar), maka motor bakar dapat dibagi menjadi 2 golongan yaitu, motor pembakaran luar, pada motor pembakaran luar ini, proses pembakaran bahan bakar terjadi di luar mesin itu, sehingga untuk melaksanakan pembakaran digunakan mesin tersendiri. Panas dari hasil pembakaran terlebih dulu melalui media penghantar, baru kemudian diubah menjadi tenaga mekanik. Misalnya; boiler, turbin uap.

Motor pembakaran dalam, pada motor pembakaran dalam, proses pembakaran bahan bakar terjadi di dalam mesin itu sendiri, sehingga panas dari hasil pembakaran langsung bisa diubah menjadi tenaga mekanik. Misalnya; turbin gas, motor bakar torak.

\section{Prinsip Kerja Motor Bensin}

Pada motor bensin, bensin dibakar untuk memperoleh energi thermal. Energi ini selanjutnya digunakan untuk melakukan gerakan mekanik. Prinsip kerja motor bensin, secara sederhana dapat dijelaskan sebagai berikut: campuran udara dan bahan bakar dari karburator dihisap masuk ke dalam silinder. Kemudian dikompresikan oleh torak saat bergerak naik. Bila campuran udara dan bahan bakar terbakar dengan adanya api dari busi, maka akan menghasilkan tekanan gas pembakaran yang besar didalam silinder. Tekanan gas pembakaran ini mendorong torak ke bawah, yang menggerakkan torak turun naik dengan bebas di dalam silinder dimana dapat di lihat pada gambar 2.1. Dari gerak lurus (naik turun) torak dirubah menjadi gerak putar pada poros engkol melalui batang torak. Gerak putar inilah yang menghasilkan tenaga pada kendaraan.

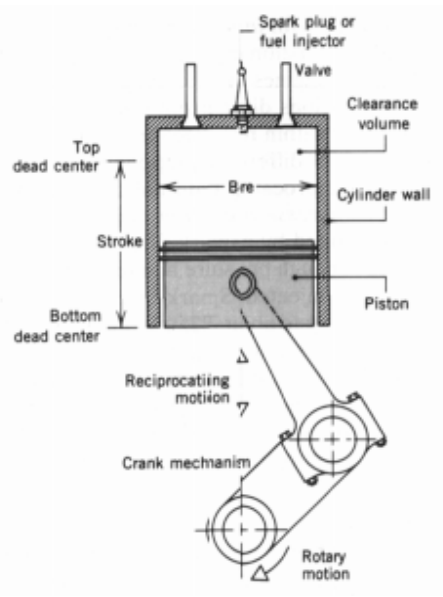

Gambar 1. Torak Dan Mekanisme Cranking

Sumber: (Salazar, F, 1998) 
Posisi tertinggi yang dicapai oleh torak di dalam silinder disebut titik mati atas (TMA), dan posisi terendah yang dicapai torak disebut titik mati bawah (TMB). Jarak bergeraknya torak antara TMA dan TMB disebut langkah torak (stroke). Campuran udara dan bahan bakar dihisap ke dalam silinder dan gas yang telah terbakar harus keluar, dan ini harus berlangsung secara tetap. Pekerjaan ini dilakukan dengan adanya gerakan torak yang turun naik didalam silinder. Proses menghisap campuran udara dan bahan bakar ke dalam silinder, mengkompresikan, membakarnya dan mengeluarkan gas bekas dari silinder, disebut satu siklus.

Ada juga mesin yang tiap siklusnya terdiri dari dua langkah torak. Mesin ini disebut mesin 2 langkah (two stroke engine). Poros engkolnya berputar satu kali selama torak menyelesaikan dua langkah. Sedangkan mesin lainnya, tiap siklusnya terdiri dari empat langkah torak. Mesin ini disebut mesin empat langkah (four stroke engine). Poros engkol berputar dua putaran penuh selama torak menyelesaikan empat langkah dalam tiap satu siklus.

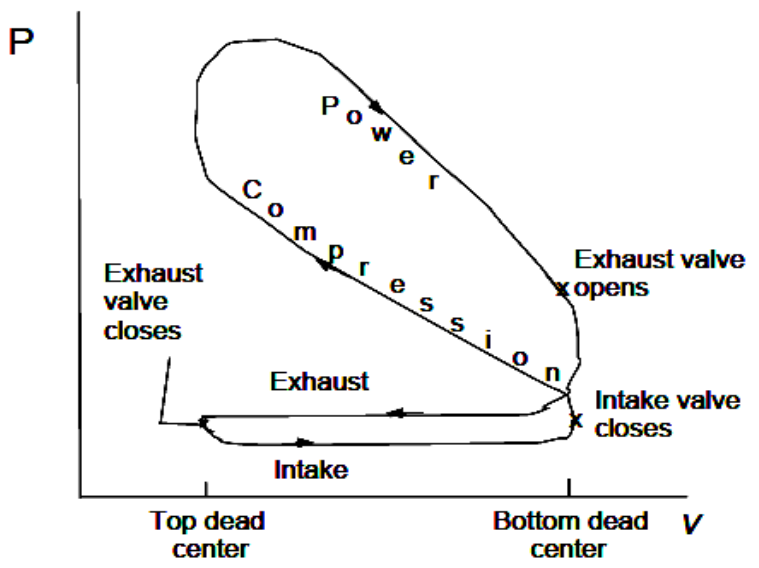

Gambar 2. Siklus Mesin

Sumber: (Penninger A, Lezsovirs F, Rohaly J and Wolff V, 2006)

\section{Prinsip Kerja Mesin 4 Langkah}

Prinsip kerja motor bensin dijelaskan pada gambar 3 berikut :
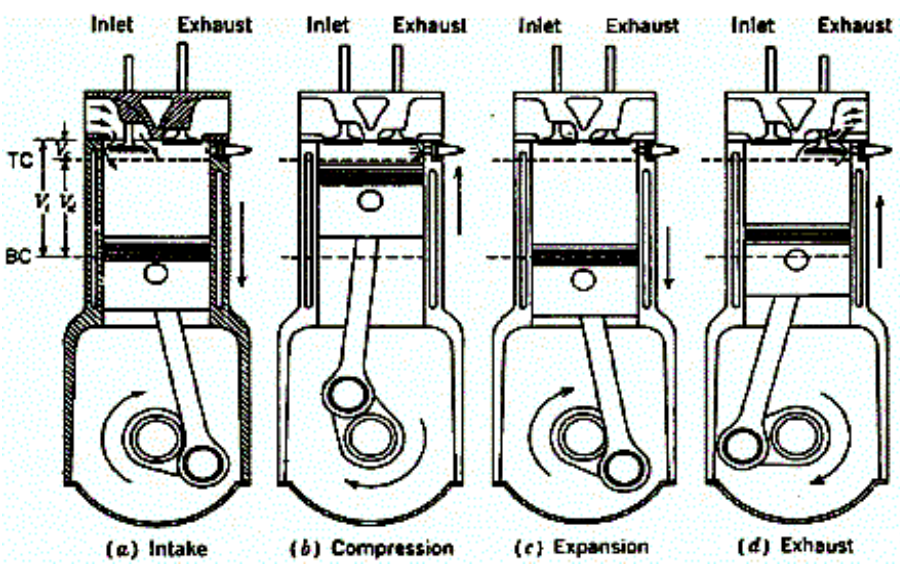

Gambar 3. Prinsip Kerja Mesin 4 Langkah

Sumber: (Penninger A, Lezsovirs F, Rohaly J and Wolff V, 2006)

Torak bergerak naik turun di dalam silinder dalam gerakan reciprocating. Titik tertinggi yang dicapai oleh torak tersebut disebut titik mati atas (TMA) dan titik terendah disebut titik mati bawah (TMB). Gerakan dari TMA ke TMB disebut langkah torak (stroke). Pada motor 4 langkah mempunyai 4 langkah dalam satu gerakan yaitu langkah penghisapan, langkah kompresi, langkah usaha dan langkah pembuangan.

Langkah hisap 
Dalam langkah ini, campuran udara dan bahan bakar dihisap ke dalam silinder. Katup masuk terbuka sedangkan katup buang tertutup. Waktu torak bergerak ke bawah, menyebabkan ruang silinder menjadi vakum, masuknya campuran udara dan bahan bakar ke dalam silinder disebabkan adanya tekanan udara luar (atmospheric pressure).

\section{Langkah Kompresi}

Dalam langkah ini, campuran udara dan bahan bakar dikompresikan. Katup hisap dan katup buang tertutup. Waktu torak mulai naik dari titik mati bawah (TMB) ke titik mati atas (TMA) campuran yang dihisap tadi dikompresikan. Akibatnya tekanan dan temperaturnya menjadi naik, sehingga akan mudah terbakar. Poros engkol berputar satu kali, ketika torak mencapai TMA.

\section{Langkah Usaha}

Dalam langkah ini, mesin menghasilkan tenaga untuk menggerakkan kendaraan. Sesaat sebelum torak mencapai TMA pada saat langkah kompresi, busi mencapai loncatan api pada campuran yang telah dikompresikan. Dengan terjadinya pembakaran, kekuatan dari tekanan gas pembakaran yang tinggi mendorong torak ke bawah. Usaha ini yang menjadi tenaga mesin (engine power).

\section{Langkah Buang}

Dalam langkah ini, gas yang terbakar dibuang dari silinder. Katup buang terbakar dibuang dari dalam silinder. Katup buang terbuka, torak bergerak dari TMB ke TMA, mendorong gas bekas keluar dari silinder. Ketika torak mencapai TMA, bergerak lagi untuk persiapan berikutnya, yaitu langkah hisap. Poros engkol telah melakukan 2 putaran penuh dalam 1 siklus terdiri dari 4 langkah, hisap kompresi, usaha, buang yang merupakan dasar kerja daripada mesin 4 langkah.

\section{Siklus Ideal Motor Bensin 4 Langkah}

Proses termodinamika dan kimia yang terjadi didalam motor bakar bensin amatlah komplek untuk dianalisa secara teoritis. Sehingga analisis tersebut maka perlu membayangkan bahwa proses ini dalam keadaan ideal. Pada umumnya untuk menganalisa motor bensin dipergunakan siklus udara sebagai siklus ideal. Pada siklus udara volume konstan (pada siklus otto) dapat digambarkan dengan grafik tekanan fungsi volume, yaitu grafik $\rho-{ }_{v}$ pada gambar 2.4 dibawah ini, yang menunjukkan diagram siklus otto dengan pemasukan volume konstan.

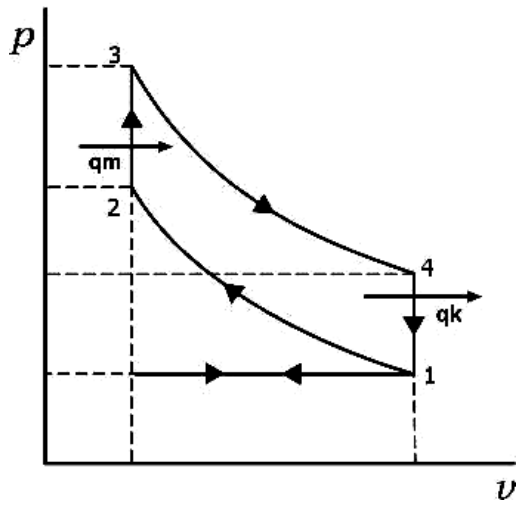

Gambar 4. Diagram Siklus Otto

Sumber: (John. B Heywood, )

Dimana:

$\mathrm{q}_{\mathrm{m}}=$ jumlah kalor yang dimasukkan

$\mathrm{q}_{\mathrm{k}}=$ jumlah kalor yang dikeluarkan

Sifat ideal yang dipergunakan serta keterangan mengenai proses siklusnya dari gambar 4 adalah sebagai berikut :

Kurva $0-1 \quad$ : langkah hisap, pada tekanan konstan.

Kurva $1-2 \quad$ : langkah kompresi, pada proses isentropis.

Kurva 2 -3 :proses pembakaran pada volume konstan, proses pemasukan kalor pada volume konstan.

Kurva 3-4 : langkah kerja pada proses ekspansi isentropis.

Kurva 4-1-0 : langkah buang. 


\section{Computational Fluid Dinamyes (CFD)}

Dalam aplikasinya, aliran fluida baik cair maupun gas adalah suatu zat yang sangat kentara dengan kehidupan sehari-hari. Misalnya pengondisian udara bagi bangunan dan mobil, pembakaran di motor bakar dan sistem propulsi, interaksi berbagai objek dengan udara atau air, aliran kompleks pada penukar panas dan reactor kimia, dan lain sebagainya, yang mana cukup menarik untuk diteliti, diselidiki dan dianalisis. Untuk kebutuhan penelitian tersebut bahkan sampai dengan tingkat desain, perlu dibutuhkan suatu alat yang mampu menganalisis atau memprediksi dengan cepat dan akurat. Maka berkembanglah suatu ilmu yang dinamakan computational fluid dynamics (CFD) yang dalam bahasa indonesia dikenal dengan komputasi aliran fluida dinamik.

\section{Proses Simulasi CFD}

Pada umumnya terdapat tiga tahapan yang harus dilakukan ketika melakukan simulasi CFD, yaitu sebagai

Preprocessing, Hal ini merupakan langkah pertama dalam membangun dan menganalisis sebuah model CFD. Teknisnya adalah membuat membuat model dalam paket CAD (computer aided design), membuat mesh yang sesuai, kemudian menerapkan kondisi batas dan sifat-sifat fluidanya. Solving

Solvers (program inti pencari solusi), CFD menghitung kondisi-kondisi yang diterapkan pada saat preprocessing. Postprocessing, Hal ini adalah langkah terakhir dalam analisis CFD. Hal yang dilakukan pada langkah ini adalah mengorganisasi dan menginterpretasi data hasil simulasi CFD yang bias berupa gambar, kurva, dan animasi.

\section{Struktur Program Fluent}

Struktur dari komponen tersebut dapat dilihat pada gambar 5

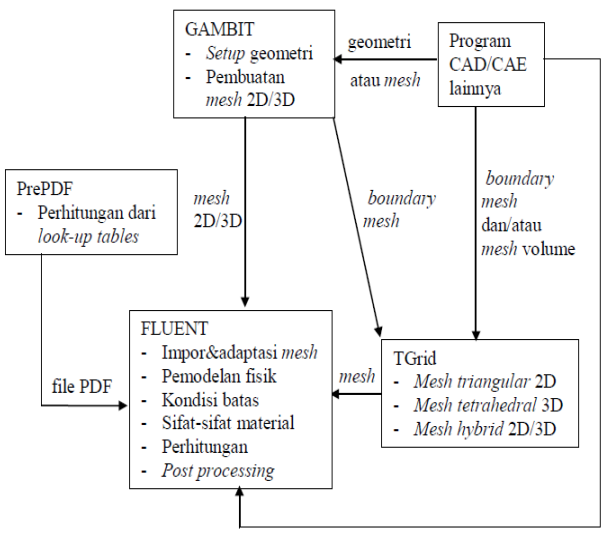

Gambar 5 Struktur Komponen Program Fluent Sumber: (Tuakia, F, 2008)

\section{METODE}

Metodologi penelitian merupakan tahap-tahap penelitian yang harus ditetapkan dahulu sebelum melakukan pemecahan masalah, sehingga penelitian dapat dilakukan dengan terarah dan memudahkan dalam menganalisis permasalahan yang ada. Berikut diagram alir Metode Penelitian yang digunakan dapat dilihat pada gambar 3.1 berikut : 


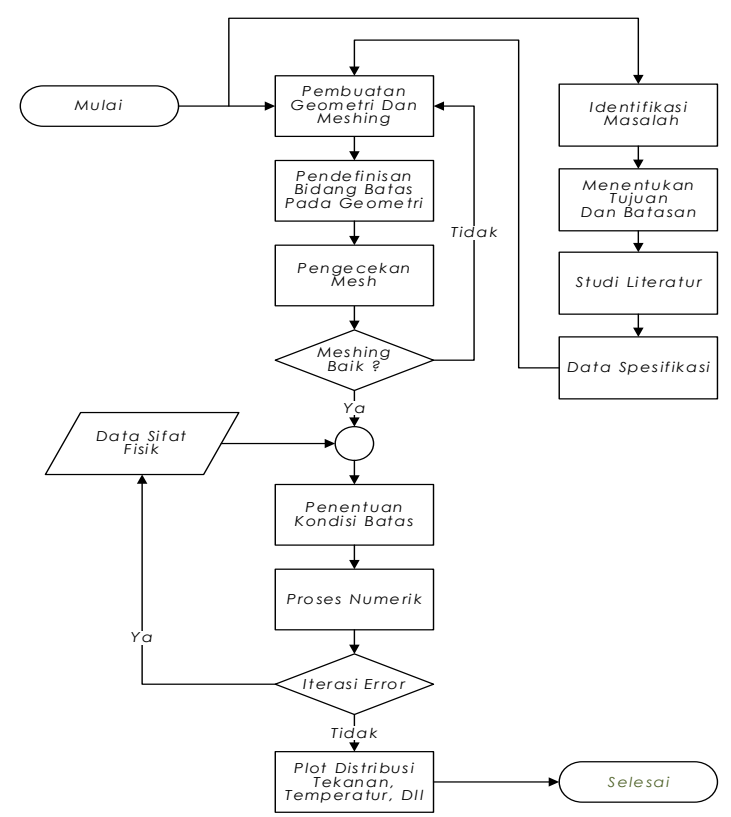

Gambar 6. Diagram Alir Proses Penelitian

\section{Prosedur Pengambilan Data}

Prosedur pengambilan data berupa permodelan dilakukan menggunakan software autodesk inventor dengan membuat model CAD domain fluida yang akandisimulasikan. Model tersebut kemudian di eksport kedalam format iges agar kompatibel dengan ANSYS FLUENT.

\section{Spesifikasi Data Dan Perhitungan}

Data yang diinput atau dikenal juga dengan boundary condition yang digunakan dalam penelitian ini berupa kecepatan udara yang divariasikan, sifat-sifat fluida yang diperoleh dari data empiris serta karakteristik injektor yang diperoleh dari produk komersial. Berikut diuraikan spesifikasi data yang digunakan:

Kecepatan aliran udara adalah $10 \mathrm{~m} / \mathrm{s}, 20 \mathrm{~m} / \mathrm{s}, 30 \mathrm{~m} / \mathrm{s}$.

Temperatur $300^{\circ} \mathrm{K}$.

Tekanan $300000 \mathrm{~Pa}$.

Karakteristik injektor.

Karakteristik injektor berdasarkan injektor merk: accel, tipe: universal, dengan spesifikasi sebagai berikut:

Flow rate $=0.003 \mathrm{~kg} / \mathrm{s}$

Vapor pressure $\quad=3 \times 105 \mathrm{bar}$

Injection inner diameter $=0.0002 \mathrm{~m}$

Atomizer $=6$

\section{Pemodelan CAD Menggunakan Autodesk Invertor}

Dalam penelitian ini akan dipelajari karakteristik semprotan atau injection bensin di bagian intake manifold pada motor bakar berbahan bakar bensin. Penelitian ini dilakukan dengan menggunakan software ANSYS FLUENT 17.1. Software ini adalah salah satu jenis program CFD yang menggunakan metode finite volume. Fluent menyediakan fleksibilitas mesh yang lengkap, sehingga dapat menyelesaikan kasus aliran fluida dengan mesh (grid) yang tidak struktur sekalipun dengan cara relatif mudah. Ukuran pemodelan intake manifold ini dibuat berdasarkan ukuran yang sebenarnya dengan cara mengukur geometri langsung di motor bakar tersebut yang berada di laboratorium thermal jurusan teknik konversi energi ISTN Jakarta. Motor bakar tersebut bisa di lihat pada gambar 3.2. 


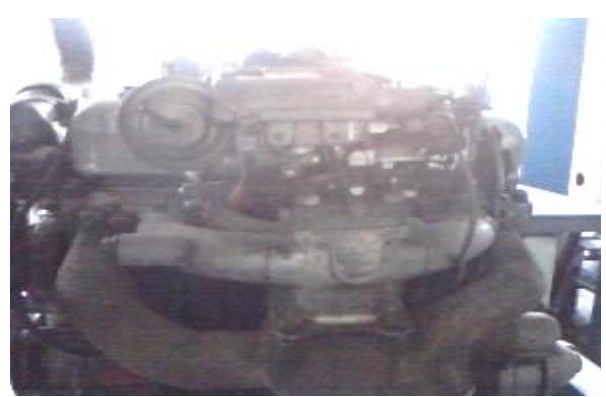

Gambar7. Foto Motor Besin Di Lab. Thermal T. Konversi Energi ISTN

Sumber: (motor FORD 2271E, $1000 \mathrm{cc}$ dapat dioperasikan dengan putaran $1000 \mathrm{rpm}, 2000 \mathrm{rpm}$, 3000rpm dan $4000 \mathrm{rpm})$

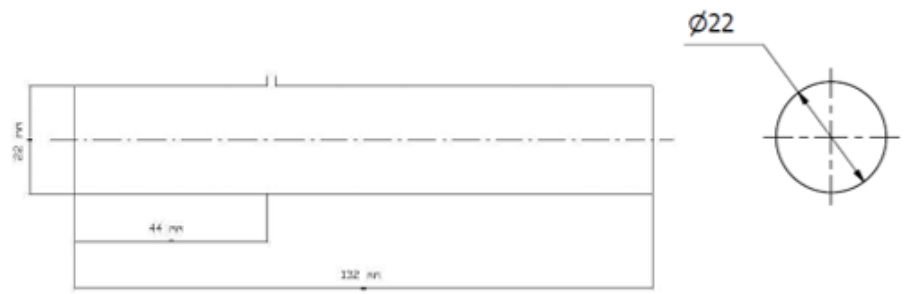

Gambar 8 Hasil Pengukuran Geometri Ruang Bakar (Intake Manifold)

Adapun langkah-langkah pembuatan model CAD pada autodesk inventor adalah membuat sketsa berdasarkan dimensi yang ada, lakukan revolution untuk membuat silinder dari sketsa, buat sketsa inlet kedua pada titik tengah silinder, lakukan extrude pada sketsa inlet kedua sehingga terbentuk silinder baru.

Berikut diuraikan langkah-langkah yang dilakukan pada software autodesk inventor, perancangan Sketsa Geometri, membuat sketsa berdasarkan dimensi yang telah diketahui, yaitu berupa gambar potongan melintang setengah silinder, dengan garis bantu diameter pada dasar bentuk kotak tersebut. Garis bantu diameter tersebut berfungsi sebagai sumbu putar sketsa kotak untuk menjadi bentuk silinder.

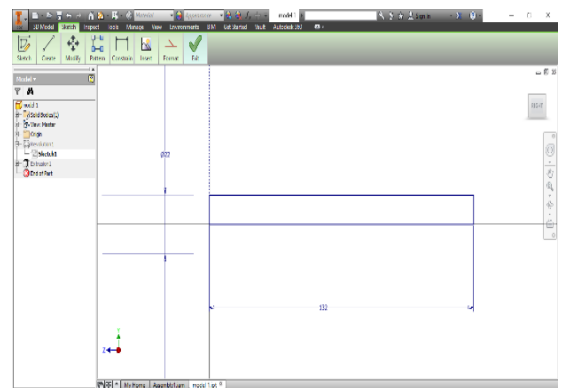

Gambar 9. Perancangan Sketsa Geometri

\section{Perancangan Sketsa Solid 3D}

Gunakan revolution sketsa tersebut terhadap sumbu putar yaitu bagian dasar sketsa sehingga menjadi model solid silinder 3D. Langkah ini berfungsi untuk "memutar" sketsa kotak yang telah kita buat pada sumbu putar tertentu yaitu dasar kotak sepanjang $360^{\circ}$ atau lingkaran penuh sehingga terbentuk model silinder yang solid.

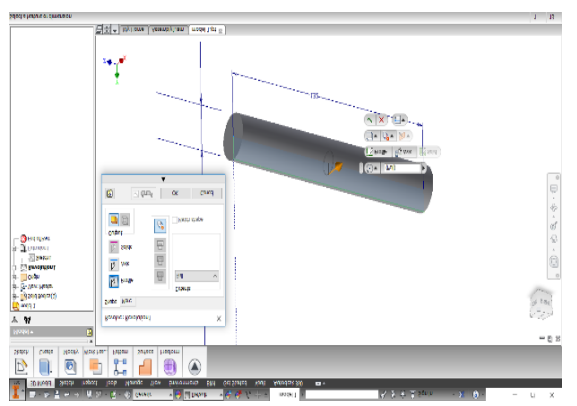

Gambar 10. Perancangan Sketsa Solid 3d 


\section{Perancangan Sketsa Inlet daan Outlet}

Buat sketsa inlet kedua dengan dimensi yang sudah ditentukan. Sketsa inlet yang kedua ini berupa lingkaran yang nantinya akan menjadi diameter dari outlet.

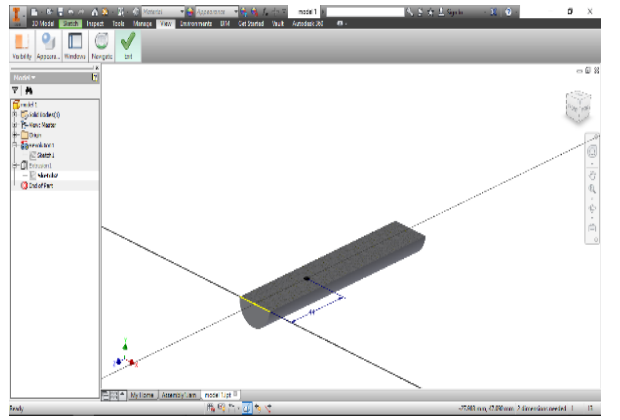

Gambar 11. Perancangan Sketsa Diameter Inlet Dan Outlet

\section{Perancangan Extrude}

Lakukan extrude pada sketsa tersebut sehingga terbentuk silinder baru. Extrude dilakukan pada sketsa lingkaran sehingga terbentuk model silinder yang solid.

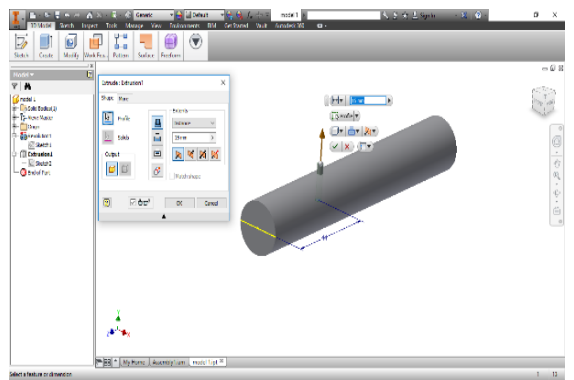

Gambar 12. Perancangan Sketsa Extrude

Dari model geometri yang sudah ada dan data-data input berupa sifat dan karakter bahan bakar yang diinput sebagai boundary condition, peneliti mengolah data-data tersebut menjadi output berupa pola aliran didalam intake manifold menggunakan bantuan program ANSYS FLUENT sehingga dapat dianalisis datanya dan dilakukan komparasi. Pengambilan data berupa pola dan karakteristik aliran tersebut dilakukan pada ansys result atau dikenal juga dengan istilah post processing.

\section{Meshing Dan Input Boundary Condition Menggunakan ANSYS}

Sebelum dilakukan analisa numerik, pertama-tama domain fluida dirubah menjadi domain komputasi, atau dikenal dengan istilah meshing atau griding. Berikut hasil meshing dari model yang digunakan pada penelitian ini beserta definisi boundary condition:

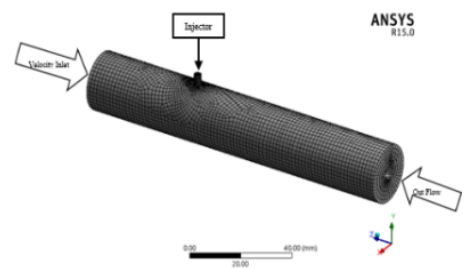

Gambar 13. Pemodelan Intake Manifold

\section{Tahapan Simulasi Numerik Menggunakan ANSYS}

Berikut ini tahapan simulasi numerik pada ansys :

1. Spesifikasi data $\mathrm{kPa}$.

Kecepatan aliran udara di intake manifold adalah $10 \mathrm{~m} / \mathrm{s}, 20 \mathrm{~m} / \mathrm{s}, 30 \mathrm{~m} / \mathrm{s}$. Temperatur $300^{\circ} \mathrm{K}$. Tekanan 300 


\section{Formulasi Solver}

Memilih formulasi solver untuk menghasilkan solusi yang akurat untuk berbagai jenis kasus melalui perintah Define $\rightarrow$ Models $\rightarrow$ Solver. Kemudian pilih formulasi solver segregated unsteady untuk digunakan dalam kasus dengan fluida inkompresibel dan kompresibel dengan kecepatan aliran fluida rendah sampai menengah (bilangan mach $<1$ ).

\section{Menentukan Persamaan Energi}

Menentukan persamaan energi untuk mengaktifkan persamaan energi yang ada di fluent untuk simulasi yang membutuhkan analisis tentang temperatur, perpindahan panas, atau radiasi. Persamaan tersebut dapat diaktifkan dengan perintah Define $\rightarrow$ Models $\rightarrow$ Energi.

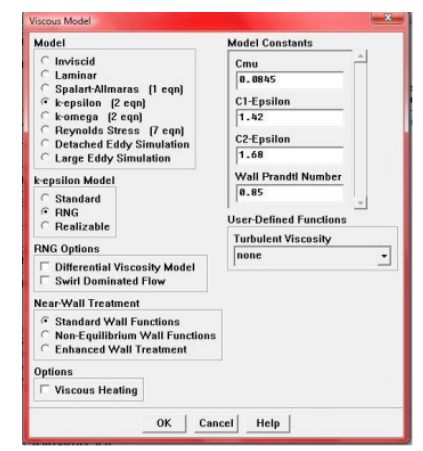

Gambar 14 Viscous Model

\section{Menentukan Pemodelan Viskositas}

Pemodelan viskositas menggunakan rng k-epsilon dengan melakukan perintah Define $\rightarrow$ Models $\rightarrow$ Viscous. Model k-epsilon merupakan model turbulensi yang cukup lengkap dengan dua persamaan yang memungkinkan kecepatan turbulen (turbulent velocity) dan length scales ditentukan secara independent.

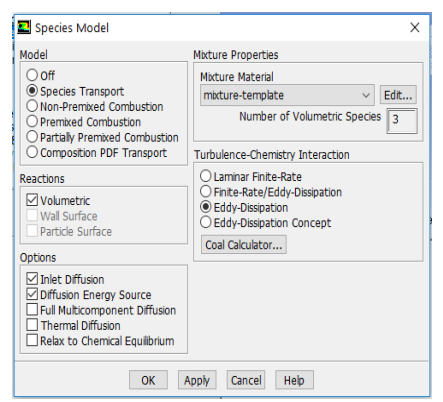

Gambar 15 Species Model

\section{Menentukan Model Species Transport Dan Reaksi Kimia}

Menentukan model species transport dan reaksi kimia dengan perintah Define $\rightarrow$ Models $\rightarrow$ Species $\rightarrow$ Transport $\rightarrow$ Species Transport. Kemudian pilih reaksi volumetrik untuk reaksi yang terjadi di fasa utama.

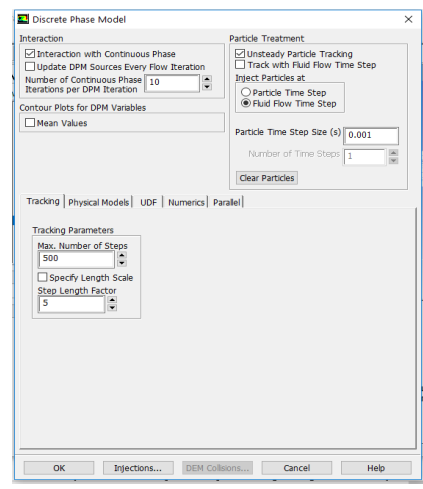

Gambar 16 Discrete Phase Model 


\section{Menentukan Model Fasa}

Menentukan model fasa melalui perinttah Define $\rightarrow$ Models $\rightarrow$ Discrete Phase $\rightarrow$ Physical Models $\rightarrow$ Droplet Breakup $\rightarrow$ Tracking $\rightarrow$ Drag Parameter $\rightarrow$ Dynamic Drag. Model aliran fasa diskrit digunakan untuk aliran gelembung, butiran, dimana volume fasa diskrit kurang dari atau sama dengan $10 \%$.

\section{Menentukan Tipe Injeksi (Injector)}

Menentukan tipe injeksi dengan melakukan perintah Define $\rightarrow$ Injections $\rightarrow$ Create $\rightarrow$ Injection Type $\rightarrow$ Pressure Swirl Atomizer $\rightarrow$ Number Of Particle Streams $=100 \rightarrow$ Particle Type $=$ Droplet $\rightarrow$ Material $=$ Gasoline.

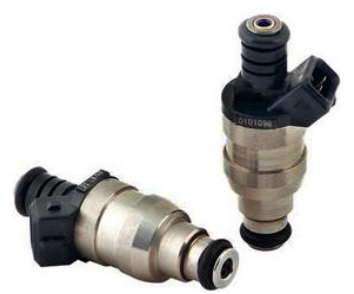

Gambar 17. Accel Fuel Injector-Universal Product

Masukan karakteristik di point properties sebagai berikut :

Flow rate

Vapor pressure $\quad=3 \times 10^{5} \mathrm{bar}$

Injection inner diameter $\quad=0.0002 \mathrm{~m}$

Atomizer $\quad=6$

Pada $s u b$ turbulent dispersion pilih discrete random walk model. Karakteristik point properties diatas berdasarkan injektor merk: accel, tipe: universal, mass flow: $0,003 \mathrm{~kg} / \mathrm{s}$, tekanan injeksi: $300000 \mathrm{~Pa}$, Pressure = 3 bar, dan diameter orifice injector: $0,2 \mathrm{~mm}=0,0002 \mathrm{~m}$.

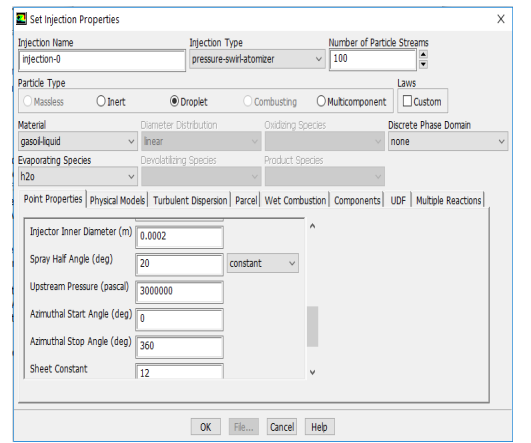

Gambar 18 Set Injection Properties

\section{Mendefinisikan Sifat Fisik Material}

Mendefinisikan sifat fisik material dengan perintah Define $\rightarrow$ Materials $\rightarrow$ Material Type $=$ Droplet Particle.

\section{Menentukan Kondisi Batas Dan Parameter Pada Kondisi Batas}

Menentukan kondisi batas dan parameter pada kondisi batas melalui perintah Define $\rightarrow$ Boundary Condition $\rightarrow$ Velocity Inlet $\rightarrow$ Velocity Magnitude $=10 \mathrm{~m} / \mathrm{s}, 20 \mathrm{~m} / \mathrm{s}, 30 \mathrm{~m} / \mathrm{s}$.

\section{Menentukan Kondisi Batas Velocity Inlet}

Kondisi batas velocity inlet digunakan untuk mendefinisikan kecepatan aliran dan dan besaran saklar lain pada sisi masuk aliran.

Menentukan Parameter Kontrol Solusi

Menentukan parameter kontrol solusi melalui perintah Solve $\rightarrow$ Control $\rightarrow$ Solution. 


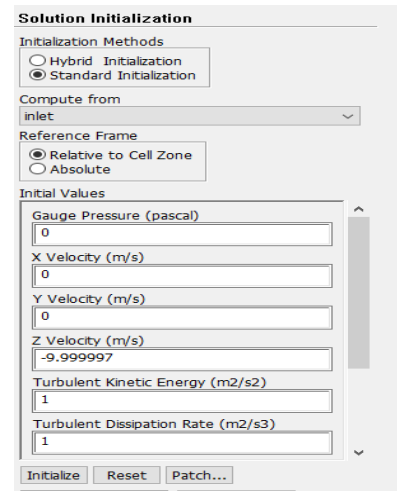

Gambar 19 Solution Initialization

\section{Proses Iterasi}

Proses iterasi memerlukan inisialisasi (tebakan awal) sebelum memulai perhitungan. Proses inisialisasi ini dapat diakses melalui perintah Solve $\rightarrow$ Initialize $\rightarrow$ Initialize... $\rightarrow$ Compute From $=$ All Zones $\rightarrow$ Init.

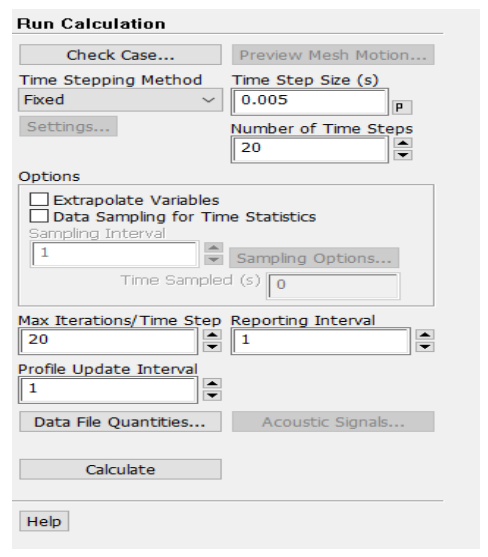

Gambar 20. Run Calculation

\section{Melakukan Perhitungan/Iterasi}

Berdasarkan setingan-setingan yang telah dipaparkan diatas pada ANSYS FLUENT, kemudian dilakukan proses iterasi atau perhitungan yaitu proses mencari solusi pada persamaan-persamaan aliran fluida pada domain yang telah kita buat sebelumnya. Untuk memonitor apakah simulasi konvergen atau tidak, dibuat plot residual, sehingga ketika terjadi solusi yang divergen dapat langsung dihentikan dan diulangi dengan setingan yang baru. Hal ini cukup penting mengingat waktu yang dibutuhkan untuk proses iterasi dapat berlangsung hingga beberapa jam bahkan bisa beberapa hari untuk simulasi yang kompleks.

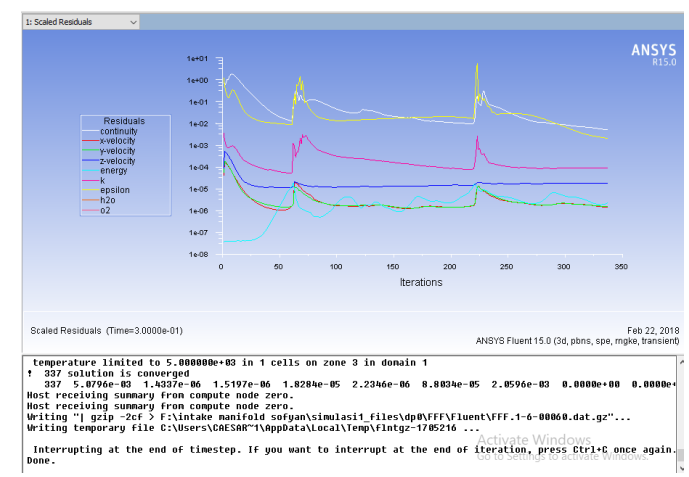

Grafik 21 Ansys Result Hasil Iterasi

Setelah solusi konvergen, data hasil simulasi pada grafik 3.16 dapat dilihat pada grafik ansys result untuk kemudian diolah datanya. Berikut tampilan jendela ansys result pada saat pengambilan data dilakukan. 
Proses pembuatan plot distribusi tekanan.

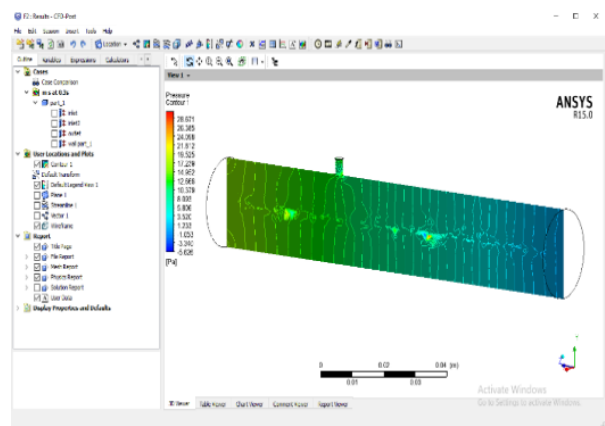

Gambar 22 Plot Distribusi Tekanan

Proses pembuatan plot distribu kecepatan

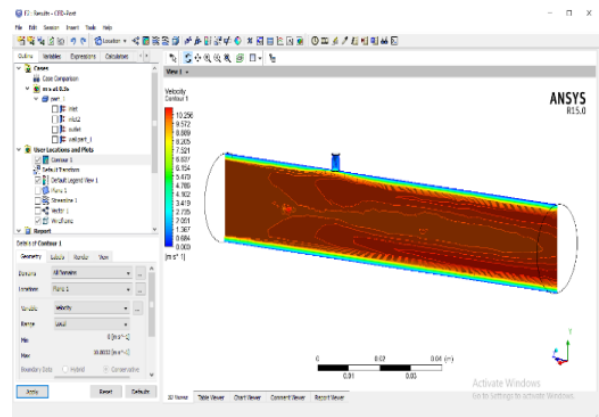

Gambar 23 Plot Pola Distribusi Kecepatan

Proses pembuatan plot pola streamline

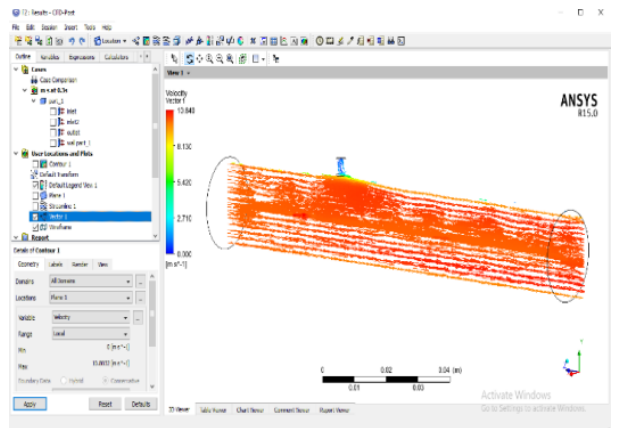

Gambar 24 Plot Pola Streamline

\section{HASIL DAN PEMBAHASAN}

Penelitian ini mengkaji beberapa variabel yang merepresentasikan karakteristik dari aliran didalam intake manifold dengan injeksi bensin, adapun variabel tersebut diantaranya yaitu kontur kecepatan dan kontur tekanan yang masing-masing divariasikan pada kecepatan inlet yaitu $10 \mathrm{~m} / \mathrm{s}, 20 \mathrm{~m} / \mathrm{s}$ dan $30 \mathrm{~m} / \mathrm{s}$. Penelitian numerik ini menggunakan bantuan software ANSYS FLUENT dalam tiga dimensi serta transient yaitu berubah terhadap waktu agar sesuai dengan kondisi aktual juga untuk mengetahui aliran di tengah maka divisualisasian dalam bidang 2D pada detik ke 0,1s. Aliran terjadi dari arah kiri ke kanan. Pemodelan turbulen standar dalam ANSYS FLUENT ini adalah rng k- $\varepsilon$ karena dinilai konservatif digunakan untuk model aliran fluida umum dan terkenal dalam kemudahanya untuk konvergen.

\section{Analisis konvergensi}

Untuk mengetahui apakah simulasi yang dilakukan konvergen atau divergen, digunakan indikator berupa plot nilai residual beberapa parameter aliran yaitu kontinuitas, kecepatan x, kecepatan y, kecepatan z, energi, k, 
epsilon dan fraksi volume komposisi fluida. Adapun nilai residual itu sendiri menunjukkan ketelitian solusi hasil simulasi dengan berapa nilai nol di belakang koma. Artinya, makin kecil nilai residual maka simulasi dikatakan cenderung konvergen. Dapat dilihat pada grafik 4.1 plot residual yang dihasilkan simulasi ini menunjukkan trend nilai residual yang cenderung turun, sehingga dapat dikatakan bahwa simulasi yang dilakukan cenderung konvergen.

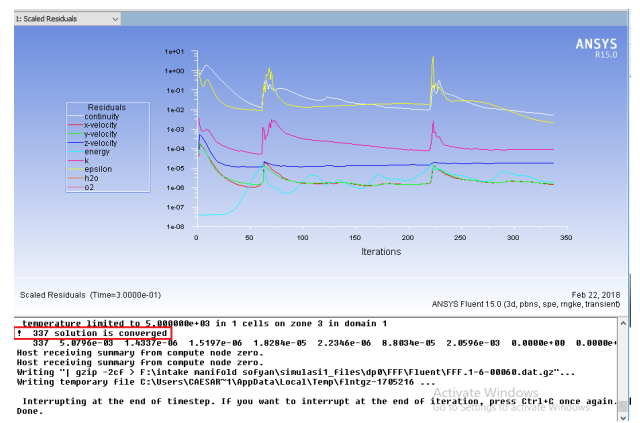

Grafik 25 Ansys Result Convergen

Adapun terdapat fluktuasi plot residual yang tiba-tiba naik diakibatkan karena simulasi yang bersifat transient, atau berubah terhadap waktu. Pada simulasi transient, setiap beberapa iterasi akan terjadi perubahan timestep yang mengharuskan iterasi diulangi pada timestep berikutnya, pengulangan iterasi pada awal timestep berikutnya inilah yang mengakibatkan grafik plot residual terlihat naik (tidak ada hubunganya dengan solusi yang divergen).

Kemudian, untuk memastikan solusi benar-benar konvergen, iterasi dilakukan hingga solusi yang diperoleh mencapai kriteria konvergen masing-masing parameter aliran. Indikator bahwa solusi telah mencapai kriteria konvergensi adalah munculnya peringatan "solution is converged" pada layar ANSYS FLUENT.

\section{Distribusi Kontur Kecepatan Aliran Udara}

Berikut disajikan distribusi kontur kecepatan aliran udara pada berbagai kecepatan inlet yaitu $10 \mathrm{~m} / \mathrm{s}, 20$ $\mathrm{m} / \mathrm{s}, 30 \mathrm{~m} / \mathrm{s}$.

Distribusi kontur kecepatan aliran udara pada kecepatan inlet $10 \mathrm{~m} / \mathrm{s}$.

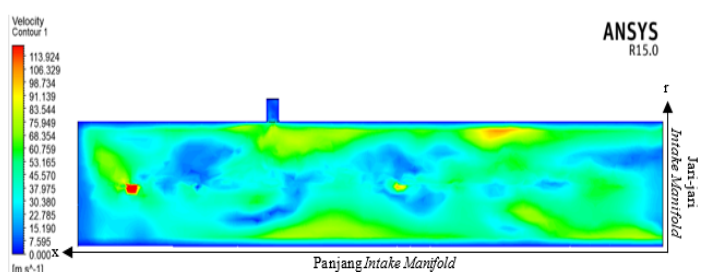

Gambar 26 Distribusi Kontur Kecepatan Aliran Udara Pada Kecepatan Inlet $10^{\mathrm{M}} / \mathrm{S}$

Distribusi kontur kecepatan aliran udara pada kecepatan inlet $20 \mathrm{~m} / \mathrm{s}$.

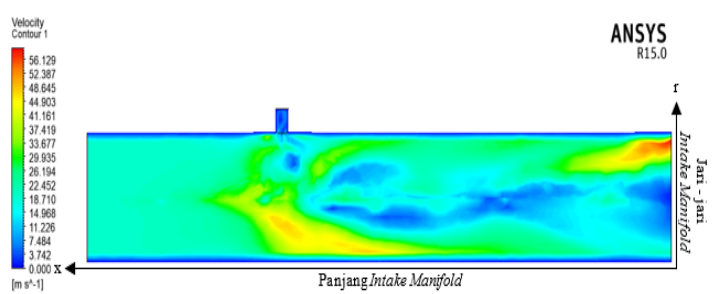

Gambar 27. Distribusi Kontur Kecepatan Aliran Udara Pada Kecepatan Inlet $20 \mathrm{M} / \mathrm{S}$

Distribusi kontur kecepatan aliran udara pada kecepatan inlet $30 \mathrm{~m} / \mathrm{s}$. 


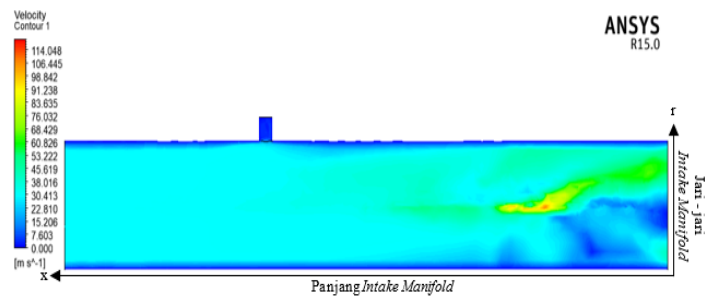

Gambar 28 Distribusi Kontur Kecepatan Aliran Udara Pada Kecepatan Inlet $30^{\mathrm{M}} / \mathrm{S}$

Dari gambar diatas dapat dilihat bahwa pada distribusi kecepatan terdapat titik dengan kecepatan yang cukup tinggi yang mana ditandai dengan kontur yang berwarna merah yang terpusat. Titik dengan kecepatan tertinggi tersebut mengindikasikan lokasi partikel yang diinjeksikan kedalam intake manifold.

Gambar menunjukkan kejadian pada detik ke 0.1s. Pada kondisi waktu tersebut, dapat diamati bahwa semakin besar kecepatan inlet mengakibatkan jarak tempuh partikel injeksi yang lebih jauh dari posisi inlet . Dapat dilihat juga dari pola kontur kecepatan diatas, pola persebaran kecepatan juga lebih merata pada kecepatan inlet yang rendah, yang berarti penyebaran bahan bakar pada intake manifold lebih merata pada kecepatan inlet yang rendah.

Daerah dekat dinding memiliki warna biru yang berarti memiliki kecepatan yang rendah. Hal ini terjadi karena efek boundary layer. Kecepatan yang rendah ini mengindikasikan daerah denngan percampuran bensin dengan udara yang kurang baik.

\section{Distribusi Vektor Kecepatan}

Guna mendukung informasi yang disajikan oleh pola kontur kecepatan, disajikan pula distribusi vektor kecepatan sehingga dapat diketahui pola aliran yang terjadi dengan lebih jelas disertai dengan arah vektor kecepatanya. Berikut disajikan distribusi vektor kecepatan pada berbagai kecepatan inlet yaitu $10 \mathrm{~m} / \mathrm{s}, 20 \mathrm{~m} / \mathrm{s}$ dan $30 \mathrm{~m} / \mathrm{s}$.

Distribusi vektor kecepatan pada kecepatan inlet $10 \mathrm{~m} / \mathrm{s}$.

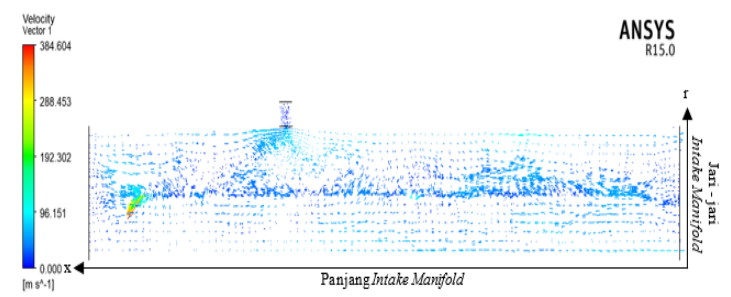

Gambar 29 Distribusi Vektor Kecepatan Pada Kecepatan Inlet $10^{\mathrm{M}} / \mathrm{S}$

Distribusi vektor kecepatan pada kecepatan inlet $20 \mathrm{~m} / \mathrm{s}$

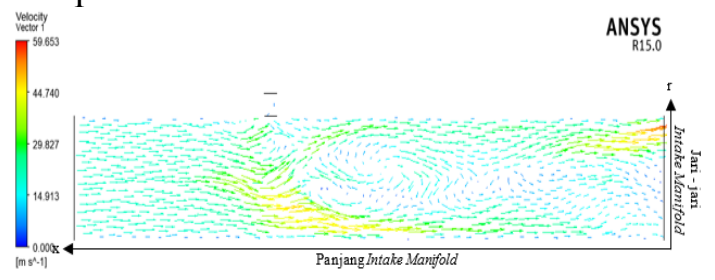

Gambar 30 Distribusi Vektor Kecepatan Pada Kecepatan Inlet $20 \mathrm{M} / \mathrm{S}$

Distribusi vektor kecepatan pada kecepatan inlet $30 \mathrm{~m} / \mathrm{s}$.

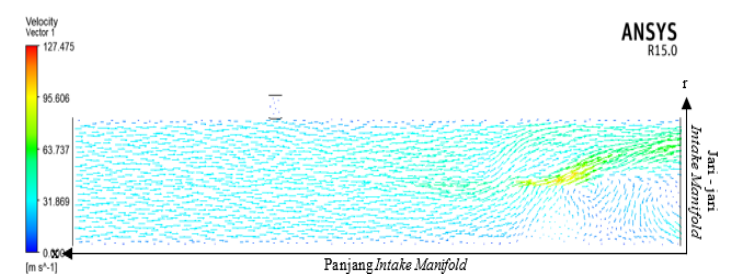

Gambar 31 Distribusi Vektor Kecepatan Pada Kecepatan Inlet $30^{\mathrm{M}} / \mathrm{S}$ 
Dari pola vektor kecepatan diatas, dapat diamati bahwa terdapat titik dengan kecepatan yang sangat tinggi yang ditandai dengan warna merah yang posisinya identik dengan yang ditunjukkan pada distribusi kontur kecepatan.

Menggunakan visualisasi vektor ini, kita dapat melihat pola aliran yang terjadi pada sekitaran titik partikel injeksi atau daerah dengan warna merah mengalami pusaran yang terpusat kearah daerah semprotan partikel. Hal ini menunjukkan terjadinya proses pencampuran antara udara dan partikel bensin pada lokasi tersebut.

Dari pola streamline terlihat aliran yang menggulung pada daerah penyemprotan bahan bakar. Hal ini menguntungkan dari segi kualitas pencampuran bahan bakar dengan udara, namun menimbulkan pressure drop atau penurunan tekanan sehingga sebagian energi kinetik hilang. Solusi yang memungkinkan dari masalah ini adalah penggunaan swirl untuk mencampur bahan bakar dengan udara pada daerah lebih lokal, sehingga pressure drop tidak terjadi pada ruang yang luas.

\section{Distribusi Kontur Tekanan}

Salah satu parameter penting yang harus dipertimbangkan dalam analisis aliran fluida adalah distribusi pola atau kontur tekanan pada aliran tersebut. Berikut disajikan distribusi vektor kecepatan pada berbagai kecepatan inlet yaitu $10 \mathrm{~m} / \mathrm{s}, 20 \mathrm{~m} / \mathrm{s}$ dan $30 \mathrm{~m} / \mathrm{s}$.

Distribusi kontur tekanan pada kecepatan inlet $10 \mathrm{~m} / \mathrm{s}$.

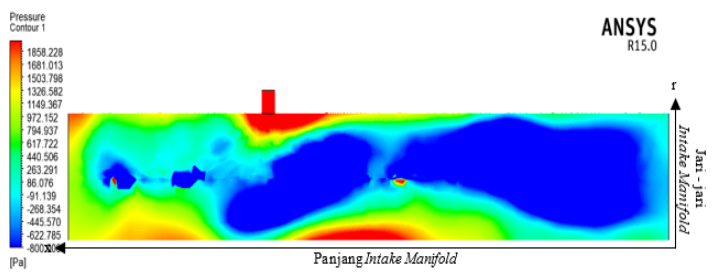

Gambar 32 Distribusi Kontur Tekanan Pada Kecepatan Inlet 10 M/S

Distribusi kontur tekanan pada kecepatan inlet $20 \mathrm{~m} / \mathrm{s}$

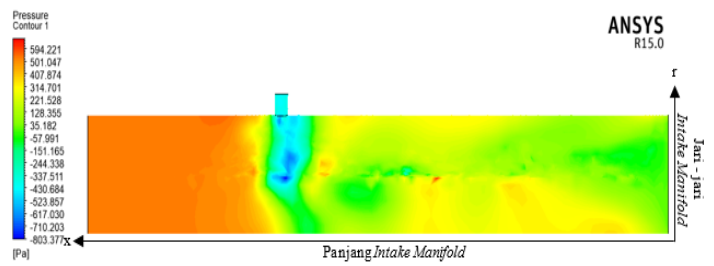

Gambar 33 Distribusi Kontur Tekanan Pada Kecepatan Inlet 20 M/s

Distribusi kontur tekanan pada kecepatan inlet $30 \mathrm{~m} / \mathrm{s}$.

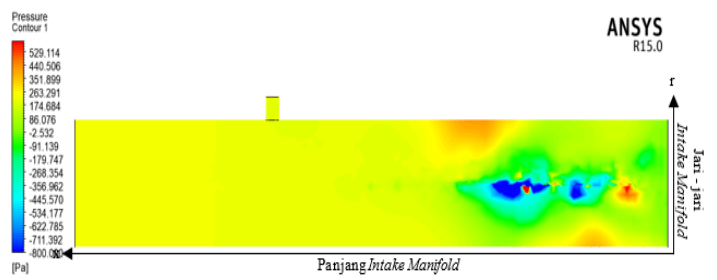

Gambar 34 Distribusi Kontur Tekanan Pada Kecepatan Inlet 30 M/S

Dapat diamati dari pola kontur tekanan diatas bahwa daerah inlet memiliki tekanan yang lebih tinggi dibandingkan dengan daerah outlet. Hal ini terjadi karena pressure drop pada sistem yang dikarenakan gesekan dengan dinding intake manifold ataupun pola aliran yang menggulung dan mengurangi energi kinetik.

Daerah dengan kecepatan tinggi yang telah diamati dari kontur kecepatan maupun vektor kecepatan diatas pada kontur tekanan ini dapat diamati warnanya menjadi biru, atau dengan kata lain menjadi sangat rendah bahkan bernilai negatif. Hal ini terjadi sesuai hukum bernouli bahwa semakin tinggi kecepatan maka tekanan pada lokasi tersebut akan semakin rendah. Adapun tekanan yang rendah tersebut menghakibatkan hisapan 
fluida kedalamnya, hal ini dapat diamati pada pola vektor kecepatan yang cenderung menuju arah semprotan partikel.

Trend yang terjadi pada kontur tekanan identik dengan kontur kecepatan, yaitu pusat tekanan minimal akan semakin tergeser posisinya ke kiri atau semakin cepat bergeser serta akan semakin cepat merata dengan bertambahnya kecepatan inlet. Kontur tekanan menunjukkan penurunan tekanan dari daerah inlet ke outlet yang memperkuat penjelasan pada plot vektor, sehingga solusi yang diberikan juga identik dengan penjelasan sebelumnya.

\section{KESIMPLAN DAN SARAN}

Dari analisis numerik yang telah menghasilkan data-data berupa plot kontur dan vektor pada berbagai variasi kecepatan inlet, menghasilkan variasi output hasil yang bervariasi pula, maka kesimpulannya adalah sebagai berikut:

a. Setingan yang dibuat pada ANSYS FLUENT mengindikasikan terjadinya daerah dengan kecepatan yang tinggi atau tekanan yang rendah pada titik tertentu yaitu titik dimana terjadinya semprotan.

b. Dapat diamati dari pola distribusi kecepatan, bahwa daerah titik dengan kecepatan yang tinggi cenderung bergeser lebih cepat seiring bertambahnya kecepatan inlet.

c. Dari pola distribusi kecepatan, dapat dilihat bahwa daerah dinding memiliki kecepatan yang rendah dikarenakan efek boundary layer. Kecepatan yang rendah ini mengindikasikan pencampuran bahan bakar dan udara yang buruk.

d. Pola distribusi vektor kecepatan mendukung penjelasan pada poin 1 dan 2 diatas degan memperlihatkan pola arah aliran. Dapat diamati bahwa terjadi pola pusaran yang terjadi pada daerah sekitar titik penyemprotan, hal ini memperlihatkan pencampuran antara bahan bakar dan udara.

e. Pola distribusi tekanan mengindikasikan trend yang sama dengan pola distribusi kecepatan, yaitu pergeserah yang relatif lebih cepat pada input kecepatan inlet yang lebih tinggi. Adapun titik penyemprotan pada pola distribusi tekanan diindikasikan dengan daerah bertekanan rendah (warna biru), mengingat hukum bernouli bahwa semakin tinggi kecepatan maka tekananya semakin rendah.

\section{REFERENCES}

Edward F Obert., (1979) Internal Combustion Engine And Air Pollution, Harper \& Row Publisher. Inc, New York.

Reitz, R D., And Bracco, F. V., (1979). On The Dependence Of Spray Angle And Other Spray Parameters On Nozzle Design And Operating Conditions, SAE Paper 790494 Dalam Heywood, J.B., 1988. Internal Combustion Engine Fundamentals, Mcgraw-Hill, Halaman.

Arai, M., Tabata, M., And Hiroyasu, H., (1984). Disintegrating Process And Spray Characterization Fuel Jet Injected By A Diesel Nozzle, Sae Paper 840275, Sae Trans., Vol. 93 Dalam Heywood, J.B.,1988. Internal Combustion Engine Fundamentals, Mcgraw-Hill, Halaman

Bpm, Arends And H. Berenschot., (1980) Terjemahan Umar Sukrisno, Motor Bensin, Erlangga, Jakarta.

M.L. Marthur \& R.P. Sharma., (1981) A Course In Internal Combustion Engine, D.R. And Sons, New Delhi.

John. B Heywood, (1988) Internal Combustion Engine Fundamentals, Mc Graw-Hill Book Company, New York.

Wiranto Arismunandar., (1988) Penggerak Mula Motor Bakar Torak, Penerbit ITB, Bandung.

Toyota Astra Motor., (2003) New Step 1 Manual Book, Jakarta.

Amien Nugroho, Ensiklopedia Otomotif, Gramedia Pustaka, Jakarta, 2005.

Baumgarten, C., (2006), Mixture Formation In Internal Combustion Engines. Springer-Verlag Berlin Heidelberg, Germany.

Ganesan, V., 2007, Internal Combustion Engines, Third Edtion. The Mcgraw-Hill Companies, New Delhi.

Tuakia, F., (2008), Dasar-Dasar CFD Menggunakan Fluent, Penerbit Informatika, Bandung. 